\title{
Early childhood caries in preschool children of Kosovo - a serious public health problem
}

\author{
Agim Begzati ${ }^{*}$, Merita Berisha², Kastriot Meqa ${ }^{3}$
}

\begin{abstract}
Background: Even though it has been widely studied, early childhood caries (ECC) remains a serious public health problem, especially in countries where there is no national program of oral health assessment and no genuine primary oral health care, such as in Kosovo. The purpose of this study was to assess the prevalence of ECC and analyze caries risk factors.

Methods: The subjects were 1,008 preschool children, selected by stratified random cluster sampling, in the municipality of Prishtina, capital of Kosovo. Data were collected through clinical examination and interviews. Dmft data were recorded according to WHO criteria. Bacterial examination (CRT bacteria test) and plaque test of GreeneVermillion were used.

Results: The mean dmft of preschool children was found to be 5.8. The prevalence of ECC was $17.36 \%$, with a mean dmft of $11 \pm 3.6$. Streptococcus mutans prevalence in ECC children was $98 \%$. A significant correlation between $\mathrm{dmft}$ and $\mathrm{S}$ mutans counts $\left(\geq 10^{5} \mathrm{CFU} / \mathrm{mL}\right.$ saliva) was demonstrated. A correlation was also found between daily sweets consumption and $\mathrm{dmft}$ in children with ECC $(P<0.001)$. Comparing the dmft of ECC children and duration of bottle feeding showed a statistical correlation $(P<0.001)$. The mean plaque test was 1.52 . None of the examined children had ever used fluoride.

Conclusion: The prevalence of ECC was high among preschool children in the municipality of Kosovo. We recommend increasing parents' knowledge of proper feeding habits and oral health practices, and increasing preschool children's accessibility to dental services.
\end{abstract}

\section{Background}

Kosovo, the youngest European country, lies in the Balkan Peninsula in Southeastern Europe. The population of Kosovo in 2000 was estimated at 2 million [1], with $32.8 \%$ of the population being age 14 or younger [2]. The health care system is facing difficult organizational issues, with many problems and challenges ahead. There are no concrete activities in preventive dentistry organized by Kosovo's Ministry of Health. Some preventive activities are accomplished by the Group for Public Oral Health Promotion, established in 2000 and supported by nongovernmental organizations.

During the promotion of oral public health in urban kindergartens, the presence of extensive dental disease

\footnotetext{
* Correspondence: agimbegzati@yahoo.com

'Department of Pedodontics and Preventive Dentistry, School of Dentistry, Medical Faculty, University of Prishtina, Prishtina, Republic of Kosovo Full list of author information is available at the end of the article
}

in children, known as early childhood caries (ECC), was recorded.

ECC is an acute, rapidly developing dental disease occurring initially in the cervical third of the maxillary incisors, destroying the crown completely. Early onset and rampant clinical progression makes ECC a serious public health problem. Due to varying clinical, etiological, localization, and course features, this pathology is found under different names such as labial caries (LC), caries of incisors, nursing bottle mouth, rampant caries (RC), nursing bottle caries (NBC), nursing caries, baby bottle tooth decay (BBTD), early childhood caries (ECC), rampant infant and early childhood dental decay, and severe early childhood caries (SECC) [3-14].

According to Davis, the definition of this pathology has always been complex and "difficult to be described, but when it is seen, you know what it's about" [15]. Up to now there have been many proposals for definition

\section{Biomed Central}

(c) 2010 Begzati et al; licensee BioMed Central Ltd. This is an Open Access article distributed under the terms of the Creative Commons Attribution License (http://creativecommons.org/licenses/by/2.0), which permits unrestricted use, distribution, and reproduction in any medium, provided the original work is properly cited. 
and diagnostic criteria, described in detail by Ismail \& Sohn [16].

The preferred and most commonly used term today is early childhood caries (ECC), proposed by the Centers for Disease Control and Prevention (CDC) [11].

The prevalence of ECC varies in different countries, which may depend on the diagnostic criteria. While in some developed countries having advanced programs for oral health protection, the prevalence of ECC is around 5\% [7,8,17-19]. In some countries of Southeastern Europe (Kosovo's neighbors), this prevalence reaches 20\% (Bosnia) and 14\% (Macedonia) [20,21]. Much higher ECC prevalence has been reported for such places as Quchan, Iran (59\%) [22] and Alaska (66.8\%) [23]. In American Indian children the prevalence is 41.8\% [23]. Similarly, in North American populations, the prevalence in high-risk children ranges from $11 \%$ to $72 \%[24]$.

Numerous biological, psychosocial, and behavioral risk factors are involved in the etiology of ECC, supporting the multifactorial character of the disease [25-27]. Based on this concept, dental caries can be defined as demineralization of tooth tissue consequent to a dental infection that is dependent on frequent exposure to fermentable carbohydrates and is influenced by saliva and fluoride and other trace elements [14].

A very important role is attributed to the bacterium Streptococcus mutans-called "the window of infection" [28], in that it is responsible for the primary oral infection in the first phase of ECC $[29,30]$.

Dietary habits are also deeply implicated in the development of ECC, despite the fact that it is considered an infectious disease [31]. Consumption of sweets with high concentrations of glucose, saccharine, or fructose, especially if taken in processed juices [32], and their prolonged intake play an important role in caries development in children with ECC [33].

The purpose of this study was to evaluate the prevalence of ECC and various caries risk factors such as quantity of cariogenic S mutans colonies, oral hygiene, sweets preference, bottle feeding in preschool children, and fluoride use.

\section{Methods}

Included in the study were 1,008 children of both sexes, from 1 to 6 years of age, from 9 kindergartens of Prishtina, capital of Kosovo. The sample was random, representing $80 \%$ of all kindergarten children. The sample size was calculated with a confidence level of $95 \%$ and a confidence interval of 2 .

\section{Dental examination and diagnostic criteria}

The children were examined in well-lit premises, using a flashlight as the light source, and a dental mirror and dental probe, by two dentists (AB and $\mathrm{KM})$. Diagnostic criteria were calibrated [34], with inter-examiner reliability resulting in kappa $=0.91$, based on the examination of 35 children of different ages.

Dental caries was scored as the number of decayed, missing, or filled primary teeth (dmft).

ECC was defined as "initial occurrence of caries in cervical region of at least two maxillary incisors." Using a careful lift-the-lip examination, the presence or absence of ECC was recorded depending on the presence of "noncavity caries/white spot lesions" or "cavity caries."

In order to study the clinical and etiological aspects of ECC, a sub-sample of children with ECC was included for further analysis. The latter part of the examination, which included the clinical study of ECC development (according to ECC stages), determination of bacterial colony sampling, oral hygiene index (OHI), and filling out of the questionnaire, was conducted in the Pediatric Dentistry Clinic of the School of Dentistry.

Children with ECC were examined using the light of the dental unit, with dental mirror and probe. All examinations were carried out by $\mathrm{AB}$, with intra-examiner reliability of kappa $=0.95$ based on the examination of 15 children of different ages.

\section{Clinical course of ECC}

In order to explain the clinical course of ECC, we propose the following stages in the occurrence and progression of carious lesions in ECC:

$\mathrm{ECC}_{\mathrm{i}}$ (initial stage)-white spot lesion or initial defect in enamel of cervix.

$\mathrm{ECC}_{\mathrm{c}}$ (circular stage)-lesion in the dentin and circular distribution of this lesion proximally.

$\mathrm{ECC}_{\mathrm{d}}$ (destructive stage)-destruction of more than half the crown without affecting the incisal edge.

$\mathrm{ECC}_{\mathrm{r}}$ (radix relicta stage)-total destruction of the crown.

The development of ECC on the maxillary incisors (at least 2) from its initial stage was monitored after a reexamination 1 year later.

\section{Bacterial sampling}

The presence of $\mathrm{S}$ mutans was determined using the CRT bacteria test (Ivoclar Vivadent, Liechtenstein) on the saliva previously stimulated by chewing paraffin. Bacterial counts were recorded as colony-forming units per milliliter $(\mathrm{CFU} / \mathrm{mL})$ of saliva.

The number of bacterial colonies was graded as follows: Class 0 and Class 1 (CFU $<10^{5} / \mathrm{mL}$ saliva), and Class 2 and Class 3 (CFU $\geq 10^{5} / \mathrm{mL}$ saliva), according to the manufacturers' scoring-card (Ivoclar-Vivadent, Lichtenstein). In younger subjects, with less saliva collected, the modified spatula method was used. 
The CRT bacteria test reacts more selectively than does the conventional agar-MSB method, thus allowing early SM detection [35].

\section{Dietary and oral hygiene questionnaire}

Parents and kindergarten teachers were asked to fill out a questionnaire about the child's dietary habits, including questions regarding frequency of sweets consumption throughout the day, as well as the type of sweets. Parents answered questions about bottle feeding: first use, duration, manner, and fluid content. They were also asked if they put their children to sleep with a bottle. Regarding tooth brushing: frequency, parents' participation during brushing, how controlled, and use of fluoride-containing toothpaste and fluoride tablets.

The OHI was determined using the Plaque Test (Ivoclar Vivadent) according to the Greene-Vermilion index.

The collected data were entered in InStat 3. The level of statistical significance was set at $P=0.05$. Statistical testing was done using the One-Way ANOVA test, and $t$ test.

This study was approved by the Ethical Board of the University Dentistry Clinical Centre of Kosova (ethics approval number N-163-2010). All participants' parents gave informed consent.

\section{Results}

\section{ECC prevalence}

From the total 1,008 examined children aged 1-6 years, the caries prevalence expressed in terms of the caries index per person, or $\mathrm{dmft}>0$, was $86.31 \%$, with a mean $\mathrm{dmft}$ of 5.8. The prevalence of ECC was $17.36 \%$, or 175 out of 1,008 examined children (Figure 1). The sub-sample of children with diagnosed ECC consisted of 150 children out of 175 invited for further analysis. Twentyfive children of this group from different kindergartens didn't show up in the Department. The mean age of children with ECC was $3.8 \pm 1.2$ years. The mean $\mathrm{dmft}$ in children with ECC was $11 \pm 3.6$. There was no statistical difference of ECC prevalence between genders $(t$ test $=1.81, P=0.07)$.

As expected, the lowest mean $\mathrm{dmft}$ score was found at age $2(6.47 \pm 2.13)$, with an age-related increase in $\mathrm{dmft}$ of 12.8 at age 6 (Table 1 ).

In comparing the mean dmft in ECC children with respect to age, there was a significant statistical difference between age 2 and ages 4, 5, and 6. (One-Way ANOVA test $\mathrm{F}=16, P<0.001)$.

\section{ECC stages}

The ECC stages were not equally distributed. The most common stage present was that of radix relicta (41.7\%), while the stage appearing least frequently was the initial stage (15.4\%), or 27 out of 150 children with ECC. There was a significant difference between the stages of ECC $\left(\chi^{2}=211.1, P<0.0001\right)$.

Twenty-five of the 27 children with ECC in the initial stage were reexamined 1 year after the baseline examination ( 2 children did not appear for reexamination due to address change). The 1-year reexamination showed that the initial stage had advanced to the circular stage in $28 \%$ of cases, destructive stage in $20 \%$, radix relicta stage in $36 \%$, and having been extracted due to ECC in $16 \%$ of cases (Table 2).

Mean age of subjects with initial stage of ECC was $2 \pm 0.7$.

Mean dmft on reexamination showed an increase from 5.1 to $8.8(P<0.001)$.

\section{$S$ mutans prevalence in ECC children}

Our results show that only a small number of children (2\%) with ECC exhibited the absence of S mutans (Class $0)$. In other words, $\mathrm{S}$ mutans prevalence in ECC children was $98 \%$. The lowest class (Class 1) was recorded in 5\%

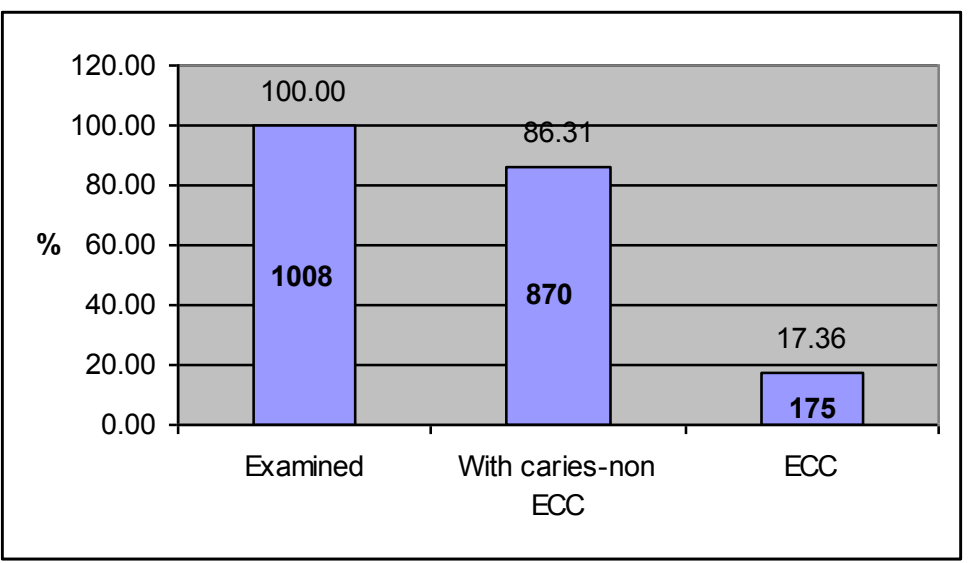

Figure 1 The ECC prevalence. 
Table 1 Mean dmft in children with ECC

\begin{tabular}{cccc}
\hline Age & $\mathbf{N}$ & Mean No. Teeth Present $\mathbf{\pm}$ SD & dmft \pm SD \\
\hline $1-2$ & 22 & $16.7 \pm 1$ & $5.5 \pm 2.1$ \\
3 & 42 & $19.1 \pm 1.3$ & $9.7 \pm 3.4$ \\
4 & 38 & $19.4 \pm 2.1$ & $12.8 \pm 2.6$ \\
5 & 36 & $18.8 \pm 3.1$ & $12.9 \pm 2.7$ \\
6 & 12 & $19.8 \pm 2.4$ & $12.8 \pm 1.3$ \\
Total & $\mathbf{1 5 0}$ & $\mathbf{1 8 . 8} \pm \mathbf{2 . 2}$ & $\mathbf{1 1} \pm \mathbf{3 . 6}$ \\
\hline
\end{tabular}

of the ECC children, while classes that represent higher risk for caries (Classes 2 and 3) were present in 34\% and 59\%, respectively, of ECC children (Table 3).

Only 11 children with ECC exhibited a low level of S mutans colonies $\left(\mathrm{CFU}<10^{5}\right)$, with the mean $\mathrm{dmft}$ of this group being 4.7. The groups with higher CFU of $\mathrm{S}$ mutans (Classes 2 and 3), representing 93\% of the children, had a mean dmft of $11.5 \pm 3$ (Table 3). Comparing the mean dmft of ECC children by $\mathrm{S}$ mutans classes of CFU showed a significant difference between Class 1 and Classes 2 and $3(\mathrm{t}=5.5, P<0.001)$.

\section{Sweets consumption}

We found that the frequency of sweets consumption in approximately $93 \%$ of the children was $1-3$ or more times a day. Sweets consumption between meals and during kindergarten hours was common.

There was a statistical correlation between daily sweets consumption and $\mathrm{dmft}$ in children with ECC (F $=7.26, P<0.001)($ Table 4).

\section{Bottle feeding in ECC children}

Most of the children with ECC represent subjects who are bottle fed up to age $2(48 \%)$ and 3 and up (39\%). Of the children with ECC, $6 \%$ were not bottle fed and 7\% were bottle fed up to age 1 . Comparing the $\mathrm{dmft}$ of ECC children with regard to duration of bottle feeding shows statistical correlation $(\mathrm{F}=20.83, P<0.001)$ (Table 4).

Tooth brushing and the $\mathrm{OHI}$ in ECC children

Regarding the frequency of tooth brushing, around 52\% of the children did not brush at all, but there was no

Table 2 ECC progression from initial stage at 1-year follow-up

\begin{tabular}{clcc}
\hline & \multicolumn{1}{c}{$\mathrm{N}$} & Baseline & Reexamination \\
\hline \multicolumn{1}{c}{ Mean dmft \pm SD } & $5.1 \pm 1.8$ & \multicolumn{1}{c}{27} \\
\hline ECC stages & Initial stage $(\mathrm{N}, \%)$ & $(27) 100 \%$ & $(0) 0 \%$ \\
\cline { 2 - 4 } & Circular stage $(\mathrm{N}, \%)$ & $/$ & (7) $28 \%$ \\
\cline { 2 - 4 } & Destructive stage $(\mathrm{N}, \%)$ & $/$ & (5) $20 \%$ \\
\cline { 2 - 4 } & Radix relicta stage $(\mathrm{N}, \%)$ & $/$ & (9) $36 \%$ \\
\cline { 2 - 4 } & Extraction $(\mathrm{N}, \%)$ & $/$ & (4) $16 \%$ \\
\hline
\end{tabular}

Table $3 \mathrm{~S}$ mutans distribution in ECC children

\begin{tabular}{lcccc}
\hline S mutans & N & $\%$ & $\begin{array}{c}\text { Mean dmft } \pm \\
\text { SD }\end{array}$ & $T$ test \\
\hline S mutans class & & & & \\
Class 0 & 3 & $2 \%$ & $3 \pm 0$ & \\
Class 1 & 8 & $5 \%$ & $5.4 \pm 2.0$ & $P<0.001$ \\
Class 2 & 51 & $34 \%$ & $9.1 \pm 3.0$ & \\
Class 3 & 88 & $59 \%$ & $12.8 \pm 2.5$ & \\
\hline S mutans values in CFU/mL & & & & \\
saliva & & & & \\
$<10^{5}(0$ and 1$)$ & 11 & $7 \%$ & $4.7 \pm 1.1$ & $T=5.5$ \\
$\geq 10^{5}(2$ and 3$)$ & 139 & $93 \%$ & $11.5 \pm 3.2$ & $P<0.001$ \\
\hline Total & 150 & $100 \%$ & $\mathbf{1 1} \pm \mathbf{3 . 6}$ & \\
\hline
\end{tabular}

statistical difference in $\mathrm{dmft}$ in terms of frequency of brushing $(\mathrm{F}=2.10, P=0.106)$.

The mean plaque test was 1.52 . No child recorded OHI-1. Although a dmft of 13 was found in children with OHI-3, no significant difference was found when comparing the $\mathrm{dmft}$ with respect to $\mathrm{OHI}(\mathrm{F}=2.52, P=$ 0.085) (Table 4).

\section{Fluoride use}

None of the mothers reported giving fluoride to their children.

\section{Discussion}

The oral health of Kosovar children is in a deplorable state, exhibiting high caries prevalence in general and high prevalence of ECC in particular.

According to WHO criteria [36], the mean dmft in the preschool children in general and the mean $\mathrm{dmft}$ in the group with ECC (5.8 and 11, respectively), may be considered very high. Furthermore, the unfavorable status of dental health services, caries risk factors, and clinical consequences, make ECC in Kosovar children a serious public health problem.

\section{Risk factors of ECC}

As the data from the literature show, the role of $S$ mutans in the etiology of ECC, especially in the initial phase, is very crucial $[28,29]$. These data also demonstrate the high prevalence of this bacterium in preschool children. S mutans is found at the earliest ages, with the prevalence of $53 \%$ in 6- to 12-month-old children [37], $60 \%$ in 15 -month-olds [38], $67 \%$ in 18 -month-old Swedes [39], and 94.7\% in 3- to 4-year-old Chinese [40]. Almost all preschool urban Icelandic children were found to carry S mutans [41]. According to the studies of Ge and Caufield, all S-ECC children were S mutanspositive [42]. Borutta [43], found that in $80 \%$ of children (3 years old) diagnosed with caries, the presence of 
Table 4 Sweets consumption, bottle feeding, and oral hygiene in ECC children

\begin{tabular}{|c|c|c|c|c|}
\hline & $\mathrm{N}$ & $\%$ & Mean dmft \pm SD & One -way ANOVA test \\
\hline \multicolumn{5}{|l|}{ Sweets consumption } \\
\hline Not every day & 10 & $7 \%$ & $6.3 \pm 2.9$ & \\
\hline Once a day & 23 & $15 \%$ & $9.9 \pm 3.8$ & $F=7.26$ \\
\hline Twice a day & 60 & $40 \%$ & $11.1 \pm 0$ & $P<0.001$ \\
\hline Three and more/day & 57 & $38 \%$ & $12.3 \pm 2.9$ & \\
\hline \multicolumn{5}{|l|}{ Bottle feeding } \\
\hline No & 9 & $6 \%$ & $4.3 \pm 1.8$ & \\
\hline Les than 1 year of age & 10 & $7 \%$ & $6.5 \pm 2.1$ & $F=20.83$ \\
\hline $1-2$ years of age & 72 & $48 \%$ & $11.8 \pm 3.2$ & $P<0.001$ \\
\hline $3+$ years of age & 59 & $39 \%$ & $11.9 \pm 2.6$ & \\
\hline \multicolumn{5}{|c|}{ Tooth brushing frequency } \\
\hline 0 & 78 & $52 \%$ & $11.1 \pm 3.7$ & $F=2.10$ \\
\hline Once a day & 59 & $39 \%$ & $10.8 \pm 3.4$ & $P=0.106$ \\
\hline Twice a day & 13 & $9 \%$ & $11.3 \pm 3.7$ & \\
\hline \multicolumn{5}{|l|}{$\overline{\mathrm{OHI}}$} \\
\hline 1 & 81 & $54 \%$ & $10.5 \pm 3.8$ & $F=1.84$ \\
\hline 2 & 60 & $40 \%$ & $11.3 \pm 3.2$ & $P=0.165$ \\
\hline 3 & 9 & $6 \%$ & $13.2 \pm 3.6$ & \\
\hline Total & 150 & $100 \%$ & $11 \pm 3.6$ & \\
\hline
\end{tabular}

$\mathrm{S}$ mutans was demonstrated, while higher counts of this bacterium were found in children with ECC.

The high prevalence of $\mathrm{S}$ mutans was also demonstrated in our study: $98 \%$ of preschool children. Expressed in colony-forming units (CFU/mL saliva), 93\% of the ECC children in our study had a high S. mutans counts $\left(\mathrm{CFU}>10^{5}\right)$. Higher salivary counts of $S$. mutans have been correlated with high $\mathrm{dmft}$ values (11.5) in our study. This significant correlation between high $\mathrm{dmft}$ or caries experience and high $\mathrm{S}$ mutans counts has been demonstrated in other studies [44-47].

In our study, the sweets consumption of children with ECC was very high. Almost 4/5 of ECC children have sweet snacks more than twice a day. It is of great concern that kindergartens as educational institutions do not have a more serious approach to a healthy diet and reduction of sugary food. On the contrary, at least once a day, sweet food (jam, chocolate, cream, biscuits, or cake) is served to children. Also, serving of this food is very common between meals. The literature also shows a high consumption of sweets between meals [48] and high caries values in children who have frequent sweets [49].

Another important factor in the etiology of ECC is bottle feeding, which is accompanied by high salivary counts of $S$ mutans. The relationship between bottle usage and salivary counts of $S$ mutans [50] has been reported. In our children, the duration of bottle feeding with sweetened milk or juice is very long, wherein nearly $4 / 5$ of children are bottle fed from 1 to 3 and more years.
Another harmful practice is putting children to sleep with a juice-filled bottle, which is practiced in $2 / 3$ of children with ECC, although Johnsen has reported that $78 \%$ of parents of children with ECC had attempted to substitute water for a cariogenic liquid (e.g., apple juice, formula) in the bedtime nursing bottle [51]. A review of the literature from the etiological point of view of ECC shows that "the use of a bottle at night" is not the only cause of ECC [52].

Oral hygiene habits established at the age of 1 can be maintained throughout early childhood [53]. There is a high level of negligence in the oral hygiene of our children. More than half do not brush their teeth at all, exhibiting a very high $\mathrm{OHI}(1.52)$. The importance of the primary dentition of oral health promotion must be focused on the education of mothers to motivate their children for oral hygiene. Unfortunately, we found "bad conviction" of mothers regarding primary teeth that they will be replaced, thus neglecting the care for children's teeth. Data from the literature show that cooperation of mothers is very important in overcoming the belief that the deciduous dentition can be neglected [54].

From the answers of mothers concerning fluoride use, we ascertained a marked lack of knowledge about the benefits of this agent in maintaining healthy tooth structure. This information gap can be inferred from their answers. When asked, "Do you give fluoride tablets to your child?" their answers were stated as if they have been asked about some medication: "I give those tablets to my child as needed." The absence of fluoride in 
Kosovo's municipal drinking water may highly influence caries prevalence rates in children.

Nutritional counseling, fluoride therapy, and oral hygiene may be required to prevent development of carious lesions in children. In the case of high-risk patients such as ECC children with a predominance of high salivary counts of $\mathrm{S}$ mutans, the use of either the antibacterial rinse chlorhexidine gluconate or the oral health care gel chlorhexidine has been suggested [55].

The oral health promotion and preventive measures are also influenced by social and economical factors. Statistical data from our country such as: large families (with average size of 6.5 members) [2], high unemployment rate (in 2008 it marked $45.4 \%$, for female 56.4\%), high birth rate $(16 \%)$ and the lowest economical growth in the region [56], represent some of the aggravating factors when dealing with the health issues of the population, including oral health issues.

Given the complexity of factors associated with ECC, it is unfortunate that most of the interest has only been from dental organizations. The critical change needed to accomplish the necessary research into the prevention of ECC is to expand our network to include other health professionals, community leaders, national organizations serving children, and political leaders [57].

\section{Consequences of ECC}

Scientific research suggests that the development of ECC occurs in 3 stages. The first stage is characterized by a primary infection of the oral cavity with ECC. The second stage is the proliferation of these organisms to pathogenic levels as a consequence of frequent and prolonged exposure to cariogenic substrates. Finally, a rapid demineralization and cavitation of the enamel occurs, resulting in rampant dental caries [24].

A 1-year follow-up of ECC development from the initial stage, representing decay at the enamel level and its progression to more destructive stages, shows even development in all affected teeth. It is quite an acute development, because in $2 / 3$ of the children, the ECC has progressed to more complicated stages (destructive and radix relicta stages). Within 1 year, the $\mathrm{dmft}$ values have increased to 3.7. Consecutively, these children commonly experience pain from pulpitis, gangrene, and apical periodontitis. Also, these conditions are often followed by abscesses and cellulitis, sometimes with phlegmona, seriously endangering the child's general health. De Grauwe, in describing the progression of ECC, has noticed that the development of caries from the enamel to the dentin level can occur within 6 months [58].

The rapid development of ECC and its clinical appearance, especially in primary incisors, identifies it in its initial stages as a risk factor for future caries in the primary and permanent dentitions [59].
Children with congenital heart anomalies are frequent patients in our departments, some of them exhibiting severe ECC.

There is strong evidence that untreated dental disease is an important etiological factor in the pathogenesis of infective endocarditis, a condition that still carries a high risk of mortality [60].

\section{Conclusions}

Caries in general and ECC in particular represent a serious public health problem for Kosovar children. Kosovar society is lacking an efficient health care system, and it has no preventive program organized by governmental institutions.

Some volunteer initiatives, such as activities of the Group for Public Oral Health Promotion, are not sufficient for achieving optimal outcome, so it is important to introduce oral health promotion.

Primary prevention must start in the prenatal stage to fulfill the needs of pregnancy. Parents should be encouraged to avoid bad feeding habits and to instruct and supervise their children in tooth brushing. Mothers should be instructed to use the lift-the-lip technique to spot the white-spot lesions as first signs of dental caries. Newly erupted teeth must be treated with fluoride agents, and, as needed, antimicrobial agents containing chlorhexidine and thymol. Further investigation is needed to assess the effectiveness of new intervention strategies beyond traditional measures that are not strictly dependent on access to dental professional providers.

\section{Acknowledgements}

The authors are most grateful to the children and their mothers for participating in this study and to the staff of the Prishtina kindergartens. We thank the Swiss Society of Odontology (SSO) and the Dental Health International Netherlands (DHIN) for their financial support of oral health promotion activities and Ivoclar-Vivadent and their representative, Dr. Gabriele David for donating CRT bacteria test and plaque test samples. For useful and professional advice, we thank Prof. Dr. Susanne Kneist, Jena University, Germany; Prof. Walter Mautsch (Aachen University School of Dentistry, Germany); and Dr. David Siegenthaler (Zurich, Switzerland).

\section{Author details}

${ }^{1}$ Department of Pedodontics and Preventive Dentistry, School of Dentistry, Medical Faculty, University of Prishtina, Prishtina, Republic of Kosovo. ${ }^{2}$ National Institute of Public Health of Kosovo, Department of Social Medicine, Medical Faculty, University of Prishtina, Prishtina, Republic of Kosovo. ${ }^{3}$ Department of Periodontology and Oral Medicine, School of Dentistry, Medical Faculty, University of Prishtina, Prishtina, Republic of Kosovo.

\section{Authors' contributions}

$\mathrm{AB}$ contributed substantially to the conception and design of the project, carried out the dental examinations, and participated in the questionnaire collection. He collected and reviewed the literature and consulted professionals in the field of study from other countries. He prepared the text. KM participated in the dental examination and in questionnaire collection, was involved in drafting and revising the manuscript, and translated it into English. MB consulted on public health issues, statistical 
analysis, and statistical comments of the manuscript. All authors have read and approved the final manuscript

\section{Competing interests}

This was not an industry-supported study. The authors declare that they have no competing interests.

Received: 26 May 2010 Accepted: 24 December 2010

Published: 24 December 2010

\section{References}

1. Demographic, social, economic situation and reproductive health in Kosovo following the 1999 conflict. Results of a household survey, November 1999- February 2000. [http://www.unfpakos.org/documents/ DHS2000.pdf], Accessed on October 15th, 2009.

2. Kosovo and its Population. Statistical Office of Kosova, September 2003, revised version. [http://www.ecmi.de/emap/download/ KosovoStatisticsFinalOne.pdf], Accessed on October 15th, 2009.

3. James PMC, Parfitt GJ, Falkner F: A study of the aetiology of labial caries of the deciduous incisor teeth in small children. Br Dent J 1957 103(2):37-40.

4. Goose DH: Infant Feeding and Caries of the Incisors: an Epidemiological Approach. Caries Res 1967, 1:167-173.

5. Fass EN: Is bottle feeding of milk a factor in dental caries? J Dent Child 1962, 29:245-251.

6. Winter GB, Hamilton MC, James PMC: Role of comforter as en etiological factor in rampant caries of deciduous dentition. Arch Dis Child 1966, 417:207-212.

7. Derkson GD, Ponti P: Nursing bottle syndrome: prevalence end etiology in a non fluoridated city. J Can Dent Assoc 1982, 6:389-393.

8. Ripa LW: Nursing caries: a comprehensive review. Pediatr Dent 1988, 10:268-282.

9. Arkin EB: The Healthy Mothers, Healthy Babies Coalition: four years progress. Public Health Rep 1986, 101:147-156.

10. Bruered B, Kinney MB, Bothwell E: Preventing baby bottle tooth decay in American Indian and Alaska native communities: a model for planning. Public Health Rep 1989, 104(6):631-640.

11. Kaste LM, Gift HC: Inappropriate Infant Bottle Feeding. Status of the Healthy People 2000 Objective. Arch Pediatr Adolesc Med 1995, 149(7):786-791.

12. Tinanoff N, Kaste LM, Corbin SB: Early childhood caries: a positive beginning. Community Dent Oral Epidemol 1998, 26(1):117-119.

13. Horowitz HS: Research issues in early childhood caries. Community Dent Oral Epidemiol 1998, 26(1):67-81.

14. Drury ThF, Horowitz AM, Ismail Al, Maertens MP, Rozier RG, Selwitz RH: Diagnosing and reporting Early Childhood Caries for Research Purposes. J Public Health Dent 1999, 59:192-197.

15. Davis GN: Early childhood caries-a synopsis. Community Dent Oral Epidemiol Munksgaard 1998, 26(1):106-116.

16. Ismail Al, Sohn W: A Systematic Review of Clinical Diagnostic Criteria of Early Childhood Caries. J Public Health Dent 1999, 59(3):171-191.

17. Kaste LM, Selwitz RH, Oldakowski RJ, Brunelle JA, Win DM, Brown LJ: Coronal Caries in the Primary and Permanent Dentition of Children and Adolescents 1-17 Years of Age:United States, 1988-1991. J Dent Res 1996, 75:631-641.

18. Davenport ES: Caries in preschool child: Aetiology. J Dent 1990, 18:300-303.

19. Hinds K, Gregory JR: National diet and nutritional survey: Children aged $1-1 / 2$ to $4-1 / 2$ years. Vol.2: Report of the dental survey. London: HMSO 1995.

20. Huseinbegović A: Social and medical aspects of primary dentition caries in urban conditions. Master degree University of Sarajevo, School of Dentistry; 2001.

21. Apostolova D, Asprovsa $V$, Simovska N: Circular caries-ECC-a problem at the earliest age [Abstract book]. 8 Congress of the Balkan Stomatological Society: 1-4 May 2003; Tirana

22. Mazhari F, Talebi M, Zoghi M: Prevalence of Early Childhood Caries and its Risk Factors in 6-60 months old Children in Quchan. Dent Res J 2007, 4(2):96-101.

23. Kelly $M$, Bruerd B: The prevalence of baby bottle tooth decay among two native American populations. J Public Health Dent 1987, 47(2):94-97.
24. Berkowitz RJ: Causes, Treatment and Prevention of Early Childhood Caries: A Microbiologic Perspective. Journal of the Canadian Dental Association 2003, 69(5):304-307.

25. Wyne AH: Early chlidhood caries: nomenclatur and case definition. Community Dent Oral Epidemiol 1999, 27:313-315.

26. Seow WK: Biological mechanisms of early childhood caries. Community Dent Oral Epidemiol 1998, 26(1):8-27.

27. Reisine S, Douglass JM: Psychosocial and behavioral issues in early childhood caries. Community Dent Oral Epidemiol 1998, 26(1):32-44.

28. Caufield PW, Cutter GR, Dasanayake AP: Initial acquisition of mutans streptococci by infants: evidence for a discrete window of infectivity. $J$ Dent Res 1993, 72(1):37-45.

29. Berkowitz RJ, Turner J, Green P: Primary oral infection of infants with Streptococcus mutans. Arch Oral Biol 1980, 25:221-224

30. Berkowitz RJ: Etiology of nursing caries; a microbiologic perspective. $J$ Public Health Dent 1996, 56(1):51-54.

31. Lopez L, Berkowitz RJ, Moss ME, Weinstein P: Mutans streptotocci prevalence in Puerto Rican babies with cariogenic feeding behaviors. Pediatr Dent 2000, 22(4):299-301.

32. Newbrun E: Sugar and dental caries: a review of human studies. Science 1982, 217(4558):418-423

33. Wendt LK, Hallonstein AL, Koch G: Dental caries in one- and two-year-old children living in Sweden. Part I - A longitudinal study. Swed Dent J 1991, 15(1):1-6.

34. Hunt RJ: Percent agreement, Pearson's correlation, and kappa as measures of inter-examiner reliability. J Dent Res 1986, 65:128-130

35. Kneist S, Laurisch L, Heinrich-Weltzein R: Der neue CRT-Mikrobiologischer hintergrund zum nachweis von S. Mutans. Oralprophylaxe 1999, 21:180-185.

36. World Health Organization. The World Oral Health Report 2003 Continuous improvement of oral health in the 21st century - the approach of the WHO Global Oral Health Programme. [http://www.who.int/oral_health/media/en/ orh_report03_en.pdf], accessed October 15th, 2010.

37. Milgrom P, Riedy CA, Weinstein P, Tanner AC, Manibusan L, Bruss J: Dental caries and its relationship to bacterial infection, hypoplasia, diet, and oral hygiene in 6- to 36-month-old children. Community Dent Oral Epidemiol 2000, 28(4):295-306

38. Karn TA, O'Sullivan DM, Tinannoff N: Colonization of mutans streptococci in 8- to 15- month-old children. J Public Health Dent 1988, 58(3):248-249.

39. Hallonsten AL, Wendt LK, Mejar I, Birkhed D, Hakansson C, Lindwall AM, Edwardsson S, Koch G: Dental Caries and prolonged breast-feeding in 18month- old. Swedish children. Int J Paediatr Dent 1995, 5(3):149-155.

40. Li Y, Navia JM, Caufield PW: Colonization by mutans streptococci in mouths of 3- and 4- year -old Chinese children with or without enamel hypoplasia. Arch Oral Biol 1994, 39(12):1057-1062.

41. Holbrook WP: Dental caries and cariogenic factors in pre-school urban Icelandic children. Caries Res 1993, 27(5):431-437.

42. Ge Y, Caufield PW, Fisch GS, Li Y: Streptococcus mutans and Streptococcus sanguinis Colonization Correlated with Caries Experience in Children. Caries Res 2008, 42:444-448.

43. Borutta A, Kneist S, Eherler DP: Oral health and Occurrence of Salivary S. mutans in Small Children. Poster J Dent Oral Med 2002, 4(3), Poster 128

44. Köhler B, Bjarnason S, Care R, Mackevica I, Rence I: Mutans streptococci and dental caries prevalence in a group of Latvian preschool children. Eur J Oral Sci 1995, 103(4):264-266.

45. Köhler B, Andreen I, Jonsson B: The earlier the colonization by mutans streptococci, the higher the caries prevalence at 4 years of age. Oral Microbiol Immunol 1988, 3:: 14-17.

46. Twetman S, Frostner N: Salivary mutans streptococci and caries prevalence in 8-year-old Swedish schoolchildren. Swed Dent J 1991, 15(3):145-151.

47. Maciel SM, Marcenes W, Sheiham A: The relationship between sweetness preference, levels of salivary mutans streptococci and caries experience in Brazilian pre-school children. International Journal of Paediatric Dentistry 2001, 11:123-130.

48. Ölmez S, Uzamis M, Erdem G: Association between early childhood caries and clinical, microbiological, oral hygiene and dietary variables in rural Turkish children. The Turkish Journal of Pediatrics 2003, 45:231-236.

49. Holbrook WP, Kristinsson MJ, Gunnarsdóttir S, Briem B: Caries prevalence, Streptococcus mutans and sugar intake among 4-year-old urban children in Iceland. Community Dent Oral Epidemiol 1989, 17(6):292-295. 
50. Mohan A, Sallivan O, Tinnannoff N: The relationship between bottle usage/content, age, and number of teeth with mutans streptococci colonization in 6-24 month old children. Community Dent Oral Epidemiol 1998, 26:12-20.

51. Johnsen DC: Characteristics and backgrounds of children with "nursing caries.". Pediatr Dent 1982, 4(3):218-224.

52. Plat $L$, Cebazas MC: Early childhood dental caries. Building community system for young children Los Angeles, CA: University of California-Los Angeles Center for Healthier Children, Families and Communities ; 2000, 32, exec. summ. (p.1).

53. Wendt LK: On oral health in infants and toddlers. Swed Dent J Supp/ 1995, 106:1-62.

54. Rosamund $\mathrm{LH}$, Tracy W: An oral health promotion program for an urban minority population of preschool children. Community dent Oral Epidemiol 2003, 31(5):392-399.

55. Featherstone JDB: The Caries Balance: The Basis for Caries Management by Risk Assessment. Oral Health Prev Dent 2004, 2(1):259-264.

56. Ministry of Public Administration. Statistical Office of Kosovo. [http://esk rks-gov.net/eng/index.php? option=com_docman\&task=doc_download\&gid=870\&ltemid=8], Accessed on October 20th, 2010

57. Ismail Al: Prevention of early childhood caries. Community dentistry and oral epidemiology 1998, 26(1):49-61.

58. De Grauwe A, Aps JK, Martens LC: Early Childhood Caries (ECC): What's in a name? Eur J Paediatr Dent 2004, 5(2):62-70.

59. Al-Shalan TA, Erickson PR, Hardie NA: Primary incisor decay before age 4 as a risk factor for future dental caries. Paediatr Dent 1997, 19(1):37-41.

60. Child JS: Risks for and prevention of infective endocarditis. In Cardiology Clinics-Diagnosis and Management of Infective Endocarditis. Volume 14. Edited by: Child JS. Philadelphia, Pa: WB Saunders Co; 1996:327-343.

\section{Pre-publication history}

The pre-publication history for this paper can be accessed here: http://www.biomedcentral.com/1471-2458/10/788/prepub

doi:10.1186/1471-2458-10-788

Cite this article as: Begzati et al:: Early childhood caries in preschool children of Kosovo - a serious public health problem. BMC Public Health 2010 10:788.

\section{Submit your next manuscript to BioMed Central and take full advantage of:}

- Convenient online submission

- Thorough peer review

- No space constraints or color figure charges

- Immediate publication on acceptance

- Inclusion in PubMed, CAS, Scopus and Google Scholar

- Research which is freely available for redistribution

Submit your manuscript at www.biomedcentral.com/submit 